\title{
Season affects energy input/output ratio in beef cattle production
}

\author{
Hayati Koknaroglu (iD. Mark Peter Hoffman
}

Hayati Koknaroglu (Corresponding author)

Isparta University of Applied Sciences, Department of Animal

Science, Isparta, Turkey.

email: hayatikoknaroglu@isparta.edu.tr

\author{
Mark Peter Hoffman \\ Iowa State University, Department of Animal Science, Ames, \\ Iowa.
}

Received: May 03, 2019 • Revised: June 13, 2019 • Accepted: June 14, 2019

\begin{abstract}
Purpose of the study was to assess the effect of season on cultural energy analysis of beef cattle production systems. For this purpose, a summer feeding trial involving 188 yearling steers, with a mean body weight of $299 \mathrm{~kg}$ which started on 28 April and finished on 3 October and a winter feeding trial involving 182 yearling steers, with a mean body weight of $327 \mathrm{~kg}$ which started on 8 November and finished on 12 April were compared. In each season, housing consisted of three outside lots with access to overhead shelter, three outside lots with no overhead shelter and a semi-enclosed (open-front) cold confinement building containing four lots. Ad libitum corn grain, $2.27 \mathrm{~kg}$ of $35 \%$ dry matter (DM) whole plant sorghum silage and $0.68 \mathrm{~kg}$ of a $61 \%$ protein-vitaminmineral supplement was offered. Cultural energy (CE) used for feed and other production inputs was derived from their corresponding lot feed consumption and their corresponding values from the literature. Transportation energy was also included in the analysis. Cattle fed in summer had higher total $\mathrm{CE}$ expenditure than those fed in winter $(\mathrm{P}<0.05)$. Feed energy constituted more than half of the total $\mathrm{CE}$ and was higher for summer fed cattle $(\mathrm{P}<0.05)$. Energy inputs/kg live weight and $/ \mathrm{kg}$ carcass were lower for summer fed cattle $(\mathrm{P}<0.05)$. Cultural energy per Mcal protein energy was higher for winter fed cattle $(\mathrm{P}<0.05)$. The energy output ratio defined as the Mcal input/Mcal output was better for summer fed cattle $(\mathrm{P}<0.05)$. Results show that time of year feeding affects cattle performance and CE use and summer feeding is an effective way of increasing the sustainability of beef cattle production.
\end{abstract}

Keywords: cultural energy, feedlot, sustainability

\section{Introduction}

Food consumption expressed in kilocalories (kcal) per capita per day is a key variable used for measuring and evaluating the evolution of the global and regional food situation (WHO 2003) and it has been increasing over the years in the world. According to the World Health Organization report, it was 2803 kcal between 1997 and 1999 and it is projected to increase to 2940 and $3050 \mathrm{kcal}$ in the year 2015 and 2030, respectively (WHO 2003). Urbanization which stimulates improvements in infrastructure including cold chains permitting trade in perishable goods, increasing income which shows a strong positive relationship with consumption of animal protein and population growth which increases food consumption put an increasing pressure on the livestock sector to meet the growing demand for high-value animal protein (WHO 2003). Annual meat production is projected to increase from 218 million tonnes in 1997-1999 to 376 million tonnes by 2030 (WHO 2003). It is estimated that the number of people fed in a year per hectare ranges from 22 for potatoes and 19 for the rice to 1 and 2, respectively, for beef and lamb (Spedding 1990). This brings another concern of the low energy conversion ratio from feed to meat as some of the cereal grain food produced is diverted to livestock production. Thus, management practices that increase animal production efficiency should be sought.

Season in which cattle are raised is one of the important factors affecting the performance of beef cattle (Koknaroglu et al 2005a; Koknaroglu et al 2005b). Sustainable agriculture defined as the management and conservation of the resource base and the orientation of technological and institutional changes in such a manner that the attainment and continued satisfaction of human needs for present and future generations will be ensured (FAO 1991) has been a subject of great interest and ongoing debate in animal agriculture (Heitschmidt et al 1996). Sustainability has gained a great importance due to an increase in the population and energy demand. The world population is increasing at a growth rate of $1.2 \%$ whereas world marketed energy consumption is increasing by 53 percent from 2008 to 2035 . Total world energy use rises from 505 quadrillion British thermal units (Btu) in 2008 to 619 quadrillion Btu in 2020 and 770 quadrillion Btu in 2035. (International Energy Annual 2011; PRB 2011).

The application of energy output/input ratios is one of the most useful methods to examine the potential long-term 
sustainability of various agricultural practices and this analysis is performed to quantify the energy return from products produced relative to the cultural energy invested to produce the product (Heitschmidt et al 1996). There has been research examining the effect of season on beef cattle performance and sustainability of broiler production (Koknaroglu et al 2005a; Koknaroglu and Atilgan 2007), no research has been conducted on the effect of season on the sustainability of beef cattle production. Thus, objectives of this study were to conduct cultural energy analysis, to compare the performance of beef cattle raised in different seasons, and to determine the effect of season on energy input/output ratio of beef cattle production.

\section{Materials and Methods}

\section{Feeding and Management}

Animal care and use committee approval was not obtained for this study, because data were obtained from an existing database. Two studies were initiated on 18 April, and 8 November and were finished on 3 October, and 12 April, respectively, and were conducted at the Allee Experimental Farm located in the center of the northwest quarter of the state of Iowa. Since steers placed on feed on 18 April and 8 November were fed mostly during warmer and colder period of the year respectively, they were defined as summer and winter feeding respectively. At the beginning of the study, the yearling steers, predominantly of Angus and Hereford breeding, were individually identified and weighed over two consecutive days. The average of these two weights was used as the starting weight (mean $\mathrm{BW}=299 \mathrm{~kg}$ for summer and mean $\mathrm{BW}=327 \mathrm{~kg}$ for winter). All steers were individually ear-tagged and, after initial weighing, the cattle were stratified by weight and color pattern and assigned to each of three types of housing facilities. Steers were weighed at 28-day intervals. The average daily gain was determined as final or intermediate weight minus initial weight divided by the number of days in the feedlot or during the period. Housing used in this study consisted of three outside lots with access to overhead shelter, three outside lots with no overhead shelter and a semienclosed (open-front) cold confinement building containing four lots. In the summer trial, cattle in open lots and open lots with access to an overhead shelter treatment had 18 steers per pen and the confinement treatment had 20 steers per pen, thus a total of 188 steers were used for the experiment. In the winter trial, cattle in open lots and open lots with access to an overhead shelter treatment had 17 steers per pen and the confinement treatment had 20 steers per pen, thus a total of 182 steers were used for the experiment. Space allocations and type of flooring were different for the three housing systems. However, they were similar to what is generally recommended and practical for cattle housing systems in the Midwest.
Consequently, they were not considered to have a direct influence on the results of this study (Pusillo et al 1991). Detailed information on housings in which steers were fed can be found in Koknaroglu et al (2008).

Steers were offered on a daily basis ad libitum corn, $2.27 \mathrm{~kg}$ of $35 \% \mathrm{DM}$ whole plant sorghum silage and $0.68 \mathrm{~kg}$ of a $61 \%$ protein-vitamin-mineral supplement.

\section{Cultural Energy Analyses}

For feedlot operations, CE used for feedlot operations for Kansas feedlots obtained from the literature was used (Lipper et al 1976). Cultural energy for feedlot operations included energy expended for receiving cattle, preparing feed, feeding, inspection, veterinary care, waste removal, loading out, and overhead (Cook et al 1980). Cultural energy used for feed for seasons was derived from their corresponding lot feed consumption and corresponding values for each feed ingredient from the literature and are given in Table 1. Transportation energy was also included in the analysis; shipping calves from the animal market and shipping yearlings to the harvesting plant accounted for the transportation energy. When calculating transportation energy, weights of cattle and distance between farm and animal purchase markets and harvesting plants were taken into consideration. Total energy expended was the summation of feed energy, feedlot operations energy, and transportation energy. When calculating energy deposited in the carcass, it was assumed that carcass content would have $18 \%$ protein and $35 \%$ fat. Energy values of $1 \mathrm{~g}$ of protein and fat were taken as $5.7 \mathrm{kcal}$ and $9.4 \mathrm{kcal}$, respectively. Total energy deposited in the carcass was calculated as carcass energy, Mcal $=$ (carcass weight $\mathrm{X}$ carcass protein ratio $\mathrm{X}$ unit protein energy) + (carcass weight $\mathrm{X}$ carcass fat ratio $\mathrm{X}$ unit fat energy). Carcass energy content for steers in the beginning of the study was calculated by using the estimated weights and the energy content of the cattle in Heitschmidt et al (1996). Energy deposited in the carcass during the experiment was calculated as total carcass energy subtracted by carcass energy deposited in the carcass when calves were put on the experiment. Efficiency, defined as CE input per energy output, was calculated by dividing total CE expended by energy deposited in the carcass. The energy required to produce a unit of protein was calculated by dividing total $\mathrm{CE}$ expended by carcass protein energy content.

\section{Statistical Analyses}

Since initial weight of steers in summer and winter differed in the beginning of the study (299 vs $327 \mathrm{~kg}$, respectively) and it is found that initial weight affects performance and CE input per energy output (Koknaroglu et al 2005a; Koknaroglu et al 2005b; Koknaroglu et al 2006; Demircan 2008), initial weight was used as a co-variate to 
eliminate the effect of initial weight. The data were analyzed using the General Linear Model procedure of SAS, and PDIFF statements were used to compare seasons.

\section{Results and Discussion}

Cultural energy input and output are represented in Table 2. Cultural energy expended on feed was higher for summer than winter $(\mathrm{P}<0.05)$. Cattle fed during summer had higher $\mathrm{CE}$ expended on feed because they had higher daily DMI $(\mathrm{P}<0.05)$ and a little longer days on feed in feedlot (Table 3). Similar results to this were found by researchers who found that cattle fed in summer had higher daily DMI than those fed in winter (Koknaroglu et al 2005b; Leu et al 1977; Muhamad et al 1983). The reason for the lower DMI in winter might be reduced water consumption and reduced digestibility of feedstuffs (Milligan and Christison 1974). Higher DMI and longer feeding duration affecting CE expended on feed by cattle receiving low levels of concentrate is well documented by Koknaroglu (2008). Cultural energy expended on feed for summer and winter constituted 56.45 and $55.96 \%$ of total CE expenditure. This is similar to findings by Koknaroglu et al (2007) who found that CE expended on feed for cattle fed in the feedlot throughout the feeding period was $61.9 \%$ of total CE expenditure. However, this was lower than that found by Cook (1976) who found that CE expended on feed for a 15,000-head feedlot operation constituted $84.6 \%$ of the total $\mathrm{CE}$ expenditure. Even though cattle fed in summer had numerically higher CE expended on feedlot operations, this was similar to that of cattle fed in winter $(\mathrm{P}>0.05)$. Cultural energy expended on feedlot operations is found by multiplying days on feed and a $1.2 \mathrm{Mcal} / \mathrm{d}$ value, which is reported by Lipper et al (1976) for Kansas feedlots. Since cattle fed in summer had a few days longer stay in feedlot (Table 3) this was reflected in their CE expended on feedlot operations. Even though cattle fed in summer had numerically higher CE expenditure for transportation than cattle fed in winter, this was not significant $(\mathrm{P}>0.05$; Table 2). Cultural energy expended for transportation was the second highest item contributing to total CE expenditure. Since using initial weight as a covariate in the model eliminates the effect of initial weight on transportation, this difference comes solely from final weight. Cattle fed in summer were heavier than winter fed cattle $(\mathrm{P}<0.05$; Table 3$)$ at the end of the trial and this is reflected in their $\mathrm{CE}$ on transportation. Koknaroglu (2008) pointed out that the distance of harvesting plant becomes more important since finished animals are heavier than cattle started on feed. Total CE expended, which is the summation of CE expended on feed, feedlot operations, and transportation is presented in Table 2. Cattle fed in summer had higher total CE expenditure than cattle fed in winter $(\mathrm{P}<0.05)$. These values are similar to values reported by Koknaroglu et al (2007a) who analyzed the integration of pasturing systems into cattle finishing programs in terms of CE use.

Table 1 Cultural energy inputs for feed, feedlot operations and transportation.

\begin{tabular}{lccc}
\hline Inputs & Unit & Mcal/unit & Reference \\
\hline Corn & $\mathrm{kg}$ & 1.23 & Sainz (2003) \\
Silage & $\mathrm{kg}$ & 0.56 & Sainz (2003) \\
Alfalfa hay & $\mathrm{kg}$ & 0.38 & Sainz (2003) \\
Soybean meal & $\mathrm{kg}$ & 1.34 & Sainz (2003) \\
Urea & $\mathrm{kg}$ & 6.93 & Sainz (2003) \\
Limestone & $\mathrm{kg}$ & 0.32 & Terhune (1980) \\
Dicalciumphosphate & $\mathrm{kg}$ & 2.39 & Calculated \\
Mineral & $\mathrm{kg}$ & 0.09 & Sainz (2003) \\
Vitamin & $\mathrm{kg}^{-1}$ & 9.89 & Calculated \\
Input for feedlot operations & Mcal head day $^{-1}$ & 1.20 & Lipper et al (1975) \\
Input for transportation & $\mathrm{kg} \mathrm{km}^{-1}$ & 0.0013 & Cook et al (1976) \\
\hline
\end{tabular}

Dividing CE expended for feed to days on feed gives CE expenditure for feed per day. Cattle fed in summer had higher CE expenditure for feed per day than winter fed cattle $(\mathrm{P}<0.05)$. The reason for this is that cattle fed in summer had higher CE expenditure on feed due to their higher DMI even though they had longer days on feed. Cultural energy expended per kg live weight gain defined as total CE expended divided by $\mathrm{kg}$ live weight gain was lower for summer fed cattle than winter fed cattle $(\mathrm{P}<0.05)$. The reason for summer fed cattle to have lower CE expenditure per $\mathrm{kg}$ of live weight gain is that they had higher ADG $(\mathrm{P}<0.05$ : Table 3$)$. Since cattle are homeotherm animals interacting with their environment (Hahn 1999) their performance is affected by their energy consumption and their energy expenditure for maintenance. The environment surrounding cattle often dictates their maintenance energy requirement and their feed 
intake (Delfino and Mathison 1991). In winter when feedlot cattle are exposed to adverse environments, the maintenance requirement increases with less energy available for production. Research has shown that when finishing steers exposed to different magnitudes (degrees below lower critical temperature) of coldness, NEm increased with decreasing temperature and NEg gradually decreased with decreasing temperature (Ames 1987). Thus, cattle raised in warmer times of the year, which requires lower NEm have higher ADG. Similar results supporting this outcome were reported by Leu et al (1977) who found that cattle fed during the winter months gained significantly less than cattle fed during summer in Iowa. Cultural energy expended per kg live weight gain in this research were comparable to values reported by Cook (1976) who found that for finishing programs under confinement feeding, each $\mathrm{kg}$ of live weight gain required 17.78 Mcal of CE and was higher than Koknaroglu et al (2007a) who fed a group of cattle in the feedlot throughout the feeding program and grazed other groups of cattle in the feedlot for different durations and finished them later in the feedlot. Although total CE expenditure of this trial and that reported in Koknaroglu et al (2007) were similar, CE expenditure per $\mathrm{kg}$ of live weight gain in this trial was higher due to higher initial weight and lower final weight leading to lower weight gain during the feeding period. In addition, lower ADG in this trial might have contributed to this outcome. Cultural energy spent per day, defined as total CE expended divided by total days on feed, was higher for summer fed cattle $(\mathrm{P}<0.05)$. The reason for this is that cattle fed in summer had higher total $\mathrm{CE}$ expenditure and a few more days on feed.

Table 2 Cultural energy input and output for seasons.

\begin{tabular}{lcc}
\hline & Summer & Winter \\
\hline CE$^{1}$ expended for feed, Mcal & $2091.13^{\mathrm{a}}$ & $2003.62^{\mathrm{b}}$ \\
CE feedlot operations, Mcal & 194.86 & 188.70 \\
CE for transportation, Mcal & 1418.21 & 1388.22 \\
Total CE expended, Mcal & $3704.20^{\mathrm{a}}$ & $3580.54^{\mathrm{b}}$ \\
CE for feed, Mcal/d & $13.15^{\mathrm{a}}$ & $12.93^{\mathrm{b}}$ \\
CE, Mcal /kg live weight gain & $19.14^{\mathrm{a}}$ & $23.88^{\mathrm{b}}$ \\
Total CE expended, Mcal/d & $23.30^{\mathrm{a}}$ & $23.10^{\mathrm{b}}$ \\
Weaning carcass energy, Mcal & 555.26 & 555.26 \\
Total carcass energy, Mcal & $1233.15^{\mathrm{a}}$ & $1128.12^{\mathrm{b}}$ \\
Energy deposited in carcass during feeding, Mcal & $677.89^{\mathrm{a}}$ & $572.87^{\mathrm{b}}$ \\
Carcass CE, Mcal/kg & $11.95^{\mathrm{a}}$ & $12.63^{\mathrm{b}}$ \\
Protein efficiency, Mcal input/Mcal protein energy output & $17.76^{\mathrm{a}}$ & $18.77^{\mathrm{b}}$ \\
Efficiency, Mcal input/Mcal output & $5.51^{\mathrm{a}}$ & $6.32^{\mathrm{b}}$ \\
\hline
\end{tabular}

${ }^{1} \mathrm{CE}$ : Cultural energy

${ }^{a, b}$ Means with different superscripts are different $(\mathrm{P}<0.05)$.

Weaning carcass energy is the energy content of the steers at the beginning of the study. Weaning carcass energy should be known because this study examines the CE expended and energy deposited in the carcass during feedlot feeding. Explanation of how weaning carcass energy is calculated is given in the material and methods section. Since initial weight was used as a co-variate weaning carcass energy for summer and winter fed steers was identical. Total carcass energy is the energy content of the carcass at the end of the trial. Summer fed cattle had a higher value than winter fed cattle due to their higher carcass weight $(\mathrm{P}<0.05$; Table 3$)$. Energy deposited in the carcass during the feeding period is found by subtracting weaning carcass energy from total carcass energy. Since summer fed cattle had higher total carcass energy and summer and winter fed cattle had identical weaning carcass energy, summer fed cattle had higher amounts of energy deposited in the carcass during feeding because of their higher carcass weight. Division of total CE expended by carcass weight gives $\mathrm{CE}$ per $\mathrm{kg}$ of the carcass. Cultural energy per $1 \mathrm{~kg}$ of the carcass was lower for summer fed cattle $(\mathrm{P}<0.05$; Table 2$)$. Similar values to these were reported by Koknaroglu et al (2007a) who integrated pasturing systems into finishing programs and analyzed it in terms of CE use. However, these values were higher than those reported by Koknaroglu (2008), Demircan and Koknaroglu (2007). Cultural energy per Mcal protein energy is given in Table 2. Summer fed cattle had lower CE per Mcal of proteinenergy than winter fed cattle $(\mathrm{P}<0.05)$. These values are similar to values reported by Koknaroglu et al (2007a) who found that cattle fed in drylot throughout the feeding period had the highest CE per Mcal of protein energy and cattle grazed on pasture for a longer time and later finished in drylot 
had the lowest CE per Mcal of protein energy. Lower values for CE per Mcal of protein are reported by Koknaroglu (2008), Demircan and Koknaroglu (2007). The reason for this is that they had lower $\mathrm{CE}$ expended on feed thus lower total $\mathrm{CE}$ expenditure due to lower levels of concentrate feeding and their comparable carcass weights. Pimentel et al (1975) found that range cattle had lower CE per Mcal of protein-energy than feedlot fed cattle. Pimentel (2004) reported that kcal of fossil energy required to produce $1 \mathrm{kcal}$ of animal protein was 40 and $20 \mathrm{kcal}$ input/ kcal protein for beef cattle fed with grain and forage mixture and those fed only with forage, respectively. Compared to other animal species CE per Mcal of protein-energy in this study was similar to those found by Koknaroglu et al (2007b), which was conducted on lamb, and higher than those reported by Koknaroglu (2010) and, Koknaroglu and Atilgan (2007) which were conducted on dairy cattle and broiler production, respectively.

Table 3. Performance of steers throughout the experiment in different seasons.

\begin{tabular}{lcc}
\hline Variables & Summer & Winter \\
\hline Actual initial weight, kg & $299^{\mathrm{a}}$ & $327^{\mathrm{b}}$ \\
Adjusted initial weight, kg & 313 & 313 \\
Final weight, kg & $510^{\mathrm{a}}$ & $467^{\mathrm{b}}$ \\
Carcass weight, kg & $311^{\mathrm{a}}$ & $285^{\mathrm{b}}$ \\
Dressing percentage & 61.01 & 60.93 \\
Days on feed & 159 & 155 \\
Daily DMI (kg/d) & $9.21^{\mathrm{a}}$ & $9.00^{\mathrm{b}}$ \\
Average daily gain, kg/d & $1.24^{\mathrm{a}}$ & $1.00^{\mathrm{b}}$ \\
Feed efficiency, kg feed/kg gain & $7.54^{\mathrm{a}}$ & $9.29^{\mathrm{b}}$ \\
\hline
\end{tabular}

${ }^{\mathrm{a}, \mathrm{b}}$ Means with different superscripts are different $(\mathrm{P}<0.05)$.

Efficiency defined as total CE expenditure divided by energy deposited in carcass during feeding is presented in Table 2. This shows the Mcal of CE expended for Mcal of food energy. Summer fed cattle had better efficiency than winter-fed cattle $(\mathrm{P}<0.05)$. Because even though they had higher total $\mathrm{CE}$ expenditure, they had higher amounts of energy deposited in the carcass during feeding due to their higher ADG and better feed efficiency. Cattle fed in summer time had better feed efficiency than winter fed cattle and the reason for this is the association between temperature and digestibility of feed. Extensive data from several experiments showed that digestibility for ruminants decreases by an average of $0.2 \%$ for each $1{ }^{\circ} \mathrm{C}$ decrease in ambient temperature (NRC 1981). Values obtained in this study are higher than those reported by Koknaroglu et al (2007a) who found that efficiency ranged between 3.26 and 4.07 for cattle fed different durations on pasture and later finished in drylot and the reason for this is that although in both studies, total CE expenditures were similar, energy deposited in the carcass during feeding in this study was lower than Koknaroglu et al (2007a). Results obtained in this study were also higher than the results obtained by Cook (1976), where he found forage fed and grain fed steers had efficiencies of 3.47 and 5.18, respectively.

\section{Conclusions}

Results of this study show that cattle fed in summer had higher CE expended on feed than cattle fed in winter. Cattle fed in summer had higher total CE expenditure than winterfed cattle. Cattle fed in summer had lower CE expended per $\mathrm{kg}$ of live weight gain, and for Mcal of protein-energy output than winter-fed cattle.

In this study, efficiency was better for cattle fed in summer than winter fed cattle and since the performance of cattle caused this outcome, this brings the measures to alleviate the effect of winter on the performance of cattle. Results show that feeding cattle during summer is an effective way of reducing CE expenditure and thus, an effective method of energy conservation and contributor to the concept of sustainable agriculture

\section{References}

Ames DR (1987) Effects of cold environment on cattle. Agri. Practice. 8(1):26.

Cook CW, Denham AH, Bartlett ET, and Child RD (1976) Efficiency of converting nutrients and cultural energy in various feeding and grazing systems. Journal of Range Management 29:186-191.

Cook CW (1976) Cultural energy expended in range meat and fiber production. Journal of Range Management 29:268-271.

Cook CW, Combs JJ, and Ward GM (1980) Cultural energy in U.S. beef production. pp. 405-418. In D. Pimentel (ed.). Handbook of Energy Utilization in Agriculture. CRC Press, Boca Raton, FL.

Delfino JG and Mathison GW (1991) Effects of cold environment and intake level on the energetic efficiency of feedlot steers. Journal of Animal Science 69:4577-4587.

Demircan V (2008) The effect of initial fattening weight on sustainability of beef cattle production in feedlots. Spanish Journal of Agricultural Research 6:17-24.

FAO (1991) Sustainable agriculture and rural development in Asia and Pacific. The Netherlands: Regional Document No. 2. FAO/ Netherlands Conf. Agric. Envir.

Hahn GL (1999) Dynamic responses of cattle to thermal heat loads. Journal of Animal Science 77:10-20 (Suppl. 2).

Heitschmidt RK, Short RE and Grings EE (1996) Ecosystems, sustainability, and animal agriculture. Journal of Animal Science 74:1395-1405.

International Energy Annual (2011) DOE/EIA-0383(2011). Annual Energy Outlook 2011 with projections to 2035. U.S. Department of Energy, Washington, DC.

Koknaroglu H, Loy DD and Hoffman MP (2005a) Effect of housing, initial weight and season on feedlot performance of steers in Iowa. South African Journal of Animal Science 35:281-289. 
Koknaroglu H, Loy DD, Wilson DE, Hoffman MP and Lawrence JD. (2005b): Factors affecting beef cattle performance and profitability. The Professional Animal Scientist 21:286-296.

Koknaroglu H, Toker MT and Bozkurt Y (2006) Effect of zeolite and initial weight on feedlot performance of Brown Swiss cattle. Asian Journal of Animal and Veterinary Advances 1:49-54.

Koknaroglu H, Ekinci K and Hoffman MP (2007a) Cultural energy analysis of pasturing systems for cattle finishing programs. Journal of Sustainable Agriculture 30:5-20.

Koknaroglu H, Ali A, Ekinci K, Morrical DG and Hoffman MP (2007b) Cultural Energy Analysis of Lamb Production in the Feedlot or on Pasture and in the Feedlot. Journal of Sustainable Agriculture 30:95-108.

Koknaroglu H and Atilgan A (2007) Effect of season on broiler performance and sustainability of broiler production. Journal of Sustainable Agriculture 31:113-124.

Koknaroglu H, Otles Z, Mader T and Hoffman MP (2008) Environmental factors affecting feed intake of steers in different housing systems in the summer. International Journal of Biometeorology 52:419-429.

Koknaroglu H (2008) Effect of concentrate level on sustainability of beef cattle production. Journal of Sustainable Agriculture 32:123136.

Koknaroglu H (2010) Cultural energy analyses of dairy cattle receiving different concentrate levels. Energy Conversion and Management 515:955-958.

Leu BM, Hoffman MP and Self HL (1977) Comparison of confinement, shelter and no shelter for finishing yearling steers. Journal of Animal Science 44:717.

Lipper RI, Anschutz JC and Weller JC (1976) Energy requirements for commercial beef cattle feedlots in Kansas. Paper presented at 1976 Mid-Central Meeting of the American Society of Agricultural Engineers, Kansas State University.
Milligan JD and Christison GL (1974) Effects of severe winter conditions on performance of feedlot steers. Canadian Journal of Animal Science 54: 605

Muhamad YB, Hoffman MP and Self HL (1983) Influence of different ratios of corn and corn silage, housing systems and seasons on the performance of feedlot steers. Journal of Animal Science $56: 747$.

NRC (1981) Effect of environment on nutrient requirements of domestic animals. National Academy of Sciences-National Research Council.Washington, D.C.

Pimentel D, Dritschilo W, Krummel J, Kutzman J (1975) Energy and land constraints in food protein production. Science 190:754-761.

Pimentel D (2004) Livestock production and energy use. Encyclopedia of Energy 3:671-676.

PRB (2011) World population data sheet. Washington, DC: Population Reference Bureau.

Pusillo GM, Hoffman MP and Self HL (1991) Effect of placing cattle on feed at two-month intervals and housing on feedlot performance and carcass grades. Journal of Animal Science 69:442-450.

Sainz RD (2003) Livestock-environment initiative fossil fuels component: Framework for calculating fossil fuel use in livestock systems. Obtained from www.fao.org.

SAS (1999) Statistical Analysis Systems user's guide (8th ed.). SAS Institute Inc., Raleigh, North Carolina.

Spedding CRW (1990) The effect of dietary changes on agriculture. In: Lewis B, Assmann G, eds. The social and economic contexts of coronary prevention. London, Current Medical Literature.

Terhune EC (1980) Energy used in the United States for agricultural liming materials. pp. 25-33. In D. Pimentel (ed.) Handbook of Energy Utilization in Agriculture. CRC Press, Boca Raton, FL.

WHO (2003) Diet, nutrition and the prevention of chronic diseases. WHO Technical Report Series 916. 